\title{
Trees and Soil Stabilization
}

Traditionally, the understanding of the function of trees in preventing soil erosion has been expressed by the maintenance, or establishment where necessary, of copses, hedgerows, etc. This tradition has characterized agricultural and rural life in Britain and many other parts of the world, and did so even before the formal introduction of forestry and land management.

It may also be noted that human impoverishment in many of the less-developed countries is due in part to soil erosion and the encroachment of desert into fertile areas due to deforestation. Historically in such countries, the problem has been caused by the need for fuel-wood for cooking, although national governments themselves, and international organizations, having recognized the imminent dangers, are now establishing reforestation programmes as rapidly as possible.

At the present stage in the development of knowledge on this subject, it seems totally unacceptable that trees should be cut down or endangered unnecessarily and indiscriminately for the personal convenience of particular individuals, and the risk of this happening has rightly stimulated, or in some cases actually induced, the formation of numerous conservation societies. All welladvised government authorities translate this public demand into legal and administrative actions directed towards the conservation and management of trees.

It is well understood that an important environmental function of trees is to establish and maintain a balance between rainfall and land drainage - by allowing the downward seepage of excess water within the soil's crevices, and the transpiration of water vapour from the soil by the leaves. Additionally, the surface roots have a soil-binding function and the canopy militates against soil desiccation while moderating the effects of wind.

The farmers of Britain and other enlightened countries have understood this for generations, so that more recently a total science of forestry and land management has evolved, and supporting legislation has been introduced. There are consequently good reasons why the destruction of useful trees by individuals for personal motives should not be tolerated.

JOHN RAWNSLEY
International Development Consultant
Pucks Oak
Compton
Guildford
Surrey GU3 $1 \mathrm{JN}$
England, UK.

\section{Future of the Forestry Work-force}

The forestry work-force is in rapid transition in North America, Europe, and other industrialized regions. There is growing concern throughout these regions as to whether a quantitatively and qualitatively adequate work-force can be attracted into the forestry sector to maintain, manage, and utilize, the regions' forests in the year 2000 and beyond.

Concerted action is needed in the forest sector, by industry, trade unions, governments, training institutions, and others, if the industry is to avert damage to the sector and to the people working in it. A seminar on the future of the forestry work-force is now being organized in the United States, to examine the wide range of issues that have to be considered in order for the forestry sector to adjust in time and in the right direction.
The seminar will be held in Corvallis, Oregon, USA, from Monday 4 to Friday 8 May 1992 under the auspices of the United States Government, the College of Forestry, Oregon State University, the Joint FAO/ECE/ILO Committee on Forest Technology, Management, and Training, and the International Union of Forest Research Organisations (IUFRO).

GEORgE BROWN, Dean
$\quad \&$
JoHn J. GARLAND, Associate Professor
College of Forestry
Oregon State University
Corvallis
Oregon 97331, USA.

\section{UNEP and Canon's International Photographic Competition 'Focus on Your World'}

\section{Introduction}

The first International Photographic Competition on the Environment has been organized by the United Nations Environment Programme (UNEP), based in Nairobi, Kenya, in cooperation with Canon, Inc., with headquarters in Tokyo, Japan. It is a world-wide competition aimed at heightening international environmental awareness. The details of the competition are as follows and should be carefully heeded by would-be beneficiaries.

From October 1991 until the end of February 1992, photographs which encapsulate the theme 'Focus on Your World' will be accepted from professional and amateur photographers around the world. Several judging stages will be used to select the winning entries. Announcement of the prize will be made at the World Environment Day ceremonies in Rio de Janeiro, Brazil, on 5 June 1992, * to

\footnotetext{
* According to a late message from UNEP's Chief of Information and Public Affairs, the awards will be presented on 6 June 1992. — Ed.
}

be celebrated during the holding of the United Nations Conference on Environment and Development (UNCED) which is to take place there from 1-12 June 1992.

The organizers invite entries that depict the beauty of our planet as well as those which encourage improvements in the control of pollution and the elimination of the destruction of natural resources which now plague the global environment and jeopardize the future of our Biosphere and very life.

\section{Numerous Prizes Offered}

In addition to the professional and amateur divisions, a children's category has also been established. A grand total of 206 photographers will be honoured with prizes, medals, cash awards, and commemorative certificates. The Gold Prize winners in the professional and amateur divisions will receive US $\$ 20,000$ and US $\$ 10,000$, respectively. Total prizes, including cash awards and Canon 